\title{
Lissarca notorcadensis (Bivalvia: Philobryidae) living on Notocidaris sp. (Echinoidea: Cidaridae): Population dynamics in limited space*
}

\author{
Thoma s Brey, Andreas Starmans, Ute Magiera and Stefan Hain \\ Alfred V'egener Institute for Polar and Marine Research, W-2850 Bremerhaven, Federal Republic of Germany
}

Received 19 May 1992; accepted 25 July 1992

Summary. Population dynamics of the epizoic bivalve Lissarca notorcadensis living on spines of cidaroid sea urchins in the Weddell Sea were investigated. Total production (somatic \& gonad) of the suspension feeding bivalve ranged between 16.5 and $487.4 \mathrm{mg} \mathrm{AFDM} \mathrm{y}{ }^{-1}$ per sea urchin. Annual sedimentation rates are not sufficient to mairtain the production of the Lissarca sub-populations carried by the sea urchins, and resuspension of organic matter is most likely to be an important food source. The ratio of the number of freshly settled juveniles to the rumber of embryos brooded is between 0.054 and 0.207 and seems negatively related to the biomass already present, indicating intraspecific competition for space. Interspecific competition for space is caused by the strong preference of $L$. notorcadensis as well as other epizoa (coloni:al anthozoans and bryozoans) for the spines located on the aboral hemispere of the sea urchins.

\section{Introduction}

The philobryid bivalve Lissarca notorcadensis MEVILL and STANDEN, 1907 is endemic to the Antarctic and exhibits a circum-Antarctic distribution in depths of 18-1120 $\mathrm{m}$ (Dell 1990). On the Weddell Sea shelf and slope it is the most common bivalve and has been subject of a recent analysis of its ecology (Brey and Hain 1992; Prezan: 1989). The suspension feeding bivalve attaches itself $b_{y}$ byssus threads to the long primary spines of cidaroirl sea urchins (see e.g. plates $1 \& 2$ in Mortensen 1920 ) and occasionally to bryozoan colonies and hydrozoan colonies. Fertilization is most likely to take place by spermatophores directly transferred to the female (Janssen 1990 ), and the young develop inside the parental mantle cavity. Fully developed juveniles are released during austral spr ng (December-January). This behaviour allows for the nvestigation of the dynamics of semi-isolated sub-

*AWI P blication No. 572

Correspondence to: $\mathrm{T}$. Brey populations of $L$. notorcadensis, e.g. those inhabiting cidaroid sea urchins with special reference to inter- and intraspecific competition for the limited space available.

\section{Methods}

During cruises of RV "Polarstern" in austral summer (JanuaryFebruary) of the years 1987, 1989 and 1991, nine specimens of the genus Notocidaris carrying Lissarca notorcadensis were handpicked from Agassiz trawl samples at five different stations (Fig. 1) and stored separately in $70 \%$ ethanol.

In the laboratory, all specimens of $L$. notorcadensis were removed from the sea urchin spines, counted and measured. Biomass was calculated from the size (i.e. maximum shell length) frequency distribution and the length (L) - mass (AFDM, ash free dry mass) relation taken from Brey and Hain (1992):

$\mathrm{mg}$ AFDM $=0.018 \cdot \mathrm{mm} \mathrm{L}{ }^{2.567} ; N=26$ size classes, 232 specimens

Somatic production was calculated by the mass specific growth rate method (see Crisp 1984) using von Bertalanffy growth curves of L. notorcadensis referring to the northern and southeastern Weddell Sea shelf (Brey \& Hain 1992):

North: $L_{t}=12.140 \cdot\left[1-\mathrm{e}^{-0.085} \cdot(\mathrm{t}-1.477)\right]$

North: $L_{t}=9.802 \cdot\left[1-e^{-0.112} \cdot(t-1.247)\right]$

Female gonad production was calculated by the relation between the number of embryos brooded in the mantle cavity $\left(N_{e m b}\right)$ and female body mass $M(\mathrm{mg})$,

North: $\mathrm{N}_{\mathrm{emb}}=-8.414+17.655 \cdot \mathrm{M} ; \mathrm{r}=0.687, \mathrm{~N}=38$

South: $\mathrm{N}_{\mathrm{emb}}=-2.923+12.477 \cdot \mathrm{M} ; \mathrm{r}=0.682, \mathrm{~N}=94$

and the average embryo mass at release, $0.031 \mathrm{mgAFDM}$. For further details of production calculations see Brey and Hain (1992). $L$. notorcadensis settles on the long primary spines of the cidaroids. Each interambulacral plate carries one of these spines (Fig. 2). The last two, three or four primary spines adjacent to the peristome are lance-shaped and are used to protect the juveniles which are carried in the peristome region (Mortensen 1909; 1946). In six of the nine cidaroids factors affecting the distribution of $L$. notorcadensis among the primary spines were analyzed. The number of bivalves per spine was determined and the spine length was measured. The amount of other epizoa, mainly anthozoan colonies and bryozoan colonies, was measured in $\mathrm{mm}$ spine length. The position of the spines on the test surface was determined by two axes, the peripherial axis (i.e. five 


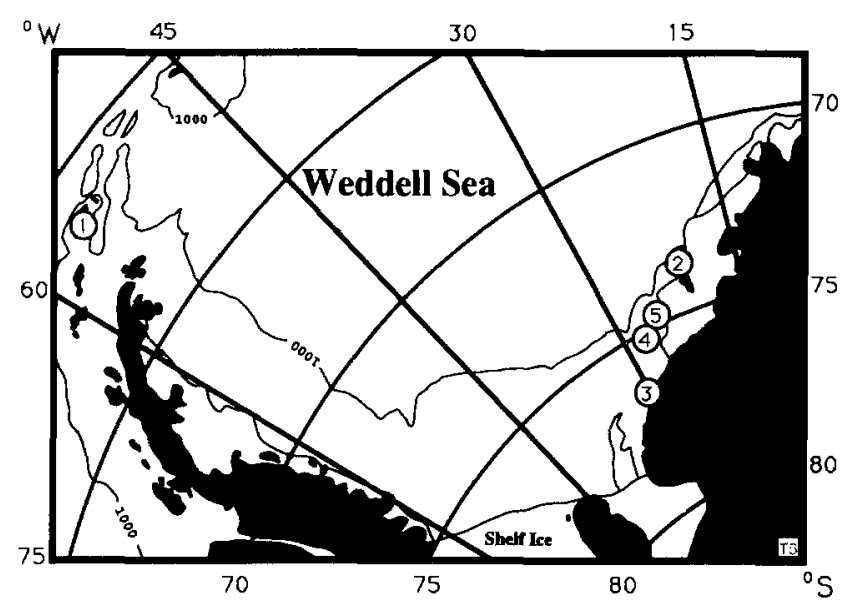

Fig. 1. Distribution of sampling stations in the Weddell Sea. 1: 15. Jan. 1989; 2: 12. Feb. 1989; 3: 12. Jan. 1987; 4: 17. Jan. 1990; 5: 9. Feb. 1990

interambulacral sectors) and the aboral-oral axis (i.e. number of interambulacral plate). Since the number of interambulacral plates increases with increasing diameter of the test, the position on the aboral-oral axis was converted from spine number to degrees $\left(0-180^{\circ}\right)$ to make different sized sea urchins comparable (Fig. 2). The data of the six specimens were pooled for the analysis of the distribution of $L$. notorcadensis on the spines, assuming that the inert nature of the spines makes interspecific differences in spine colonization unlikely.

\section{Results}

\section{Abundance and biomass}

The nine specimens of Notocidaris sp. ranged from 30 to $63 \mathrm{~mm}$ diameter and should have carried between 65 and 95 primary spines. Between 41 and 72 of these were still present, 1 to 31 spines were completely lost, most likely during trawling. Abundance and biomass values of Lissarca notorcadensis ranged from 65 ind. \& $31.0 \mathrm{mg}$ AFDM to 1241 ind. \& $942.7 \mathrm{mg}$ AFDM per sea urchin (Table 1). Figure 3 shows the length-frequency distributions of $L$. notorcadensis inhabiting the nine cidaroids.

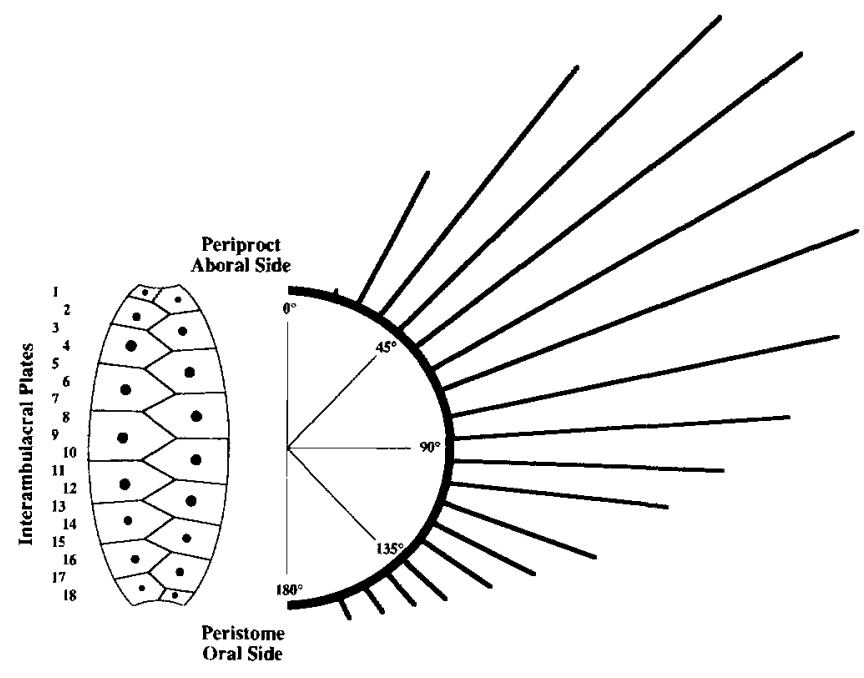

Fig. 2. Schematic drawing (front view and sectional view) of an interambulacral sector of a cidaroid with 18 interambulacral plates. The relation of spine length to test diameter is true to scale

\section{Production}

Somatic $\left(\mathrm{P}_{\mathrm{s}}\right)$ and gonad production $\left(\mathrm{P}_{\mathrm{g}}\right)$ of L. notorcadensis ranged between $13.1 \& 342.0 \mathrm{mg} \mathrm{AFDM} \mathrm{y}^{-1}$ and $3.4 \& 145.4 \mathrm{mg} \mathrm{AFDM} \mathrm{y}^{-1}$ per sea urchin, respectively. Annual production/biomass $(\mathrm{P} / \mathrm{B})$ ratios were between 0.309 and 0.424 (somatic) and 0.109 and 0.154 (gonad), respectively. Total production $\left(\mathrm{P}_{\mathrm{t}}\right)$ ranged from $16.5 \mathrm{mg}$ $\mathrm{AFDM} \mathrm{y}^{-1}$ to $487.4 \mathrm{mg} \mathrm{AFDM} \mathrm{y}{ }^{-1}$, and the total P/B ratio was in the range of $0.432 \mathrm{y}^{-1}$ to $0.552 \mathrm{y}^{-1}$ (Table 1).

\section{Recruitment}

Recruitment success of each $L$. notorcadensis sub-population inhabiting one sea urchin was estimated from the relation between the number of embryos brooded by the population $\left(\mathrm{N}_{\mathrm{emb}}\right)$ and the number of recently recruited juveniles $\leqq 1.7 \mathrm{~mm}$ in the population $\left(\mathrm{N}_{\text {juv }}\right.$, first peak of size-frequency distribution in Fig. 3). Recruitment success, i.e. $\mathrm{N}_{\text {juv }}$ as fraction of $\mathrm{N}_{\mathrm{emb}}$, is 0.110 on the average, ranging from 0.054 to 0.207 . There is a weak negative

Table 1. The investigated sea urchins and their populations of $L$. notorcadensis. Units of mass are mg AFDM

\begin{tabular}{|c|c|c|c|c|c|c|c|c|c|c|c|c|c|c|}
\hline \multirow[b]{2}{*}{ No } & \multirow[b]{2}{*}{$\begin{array}{l}\text { Depth } \\
\mathrm{m}\end{array}$} & \multirow[b]{2}{*}{ Area } & \multicolumn{3}{|c|}{ Notocidaris sp. } & \multicolumn{9}{|c|}{ Lissarca notorcadensis } \\
\hline & & & $\begin{array}{l}\text { Diam. } \\
\text { mm }\end{array}$ & Spines & $\begin{array}{l}\text { Spines } \\
\text { lost }\end{array}$ & $\mathrm{N}$ & $\begin{array}{l}\text { B } \\
\mathrm{mg}\end{array}$ & $\begin{array}{l}\mathrm{M} \\
\mathrm{mg}\end{array}$ & $\begin{array}{l}P_{s} \\
m g y^{-1}\end{array}$ & $\begin{array}{l}\mathrm{P}_{\mathrm{g}} \\
\mathrm{mg} \mathrm{y}\end{array}$ & $\begin{array}{l}P_{t} \\
m g y^{-1}\end{array}$ & $\begin{array}{l}\mathrm{P}_{\mathrm{s}} / \mathrm{B} \\
\mathrm{y}^{-1}\end{array}$ & $\begin{array}{l}\mathrm{P}_{\mathrm{g}} / \mathrm{B} \\
\mathrm{y}\end{array}$ & $\begin{array}{l}\mathrm{P}_{\mathbf{t}} / \mathrm{B} \\
\mathrm{y}^{-1}\end{array}$ \\
\hline $1 \mathrm{a}$ & 414 & North & 59 & 75 & 24 & 438 & 269.6 & 0.62 & 93.7 & 38.5 & 132.2 & 0.348 & 0.143 & 0.490 \\
\hline $1 \mathrm{~b}$ & 414 & North & 56 & 95 & 34 & 1241 & 942.7 & 0.76 & 342.0 & 145.4 & 487.4 & 0.363 & 0.154 & 0.517 \\
\hline 1c & 414 & North & 63 & 95 & 21 & 421 & 242.7 & 0.58 & 84.1 & 35.4 & 119.5 & 0.347 & 0.146 & 0.492 \\
\hline $2 a$ & 294 & South & 30 & 65 & 1 & 148 & 52.0 & 0.35 & 23.0 & 5.7 & 28.7 & 0.442 & 0.110 & 0.552 \\
\hline $2 b$ & 294 & South & 55 & 80 & 18 & 73 & 44.8 & 0.61 & 13.9 & 5.5 & 19.4 & 0.309 & 0.123 & 0.432 \\
\hline $2 c$ & 294 & South & 50 & 80 & 21 & 84 & 45.8 & 0.54 & 15.9 & 5.9 & 21.8 & 0.348 & 0.129 & 0.477 \\
\hline 3 & 358 & South & 54 & 65 & 24 & 65 & 31.0 & 0.48 & 13.1 & 3.4 & 16.5 & 0.424 & 0.109 & 0.532 \\
\hline 4 & 427 & South & 37 & 65 & 10 & 149 & 92.9 & 0.62 & 29.4 & 12.1 & 41.5 & 0.317 & 0.130 & 0.447 \\
\hline 5 & 475 & South & 42 & 70 & 4 & 289 & 169.2 & 0.59 & 57.7 & 21.3 & 79.0 & 0.341 & 0.126 & 0.467 \\
\hline
\end{tabular}

$\mathrm{N}$ : Number of bivalves per sea urchin; B, M: Biomass, mean individual body mass; $P_{s}, P_{g}$, $P_{t}$ : Somatic, gonadal, total production 

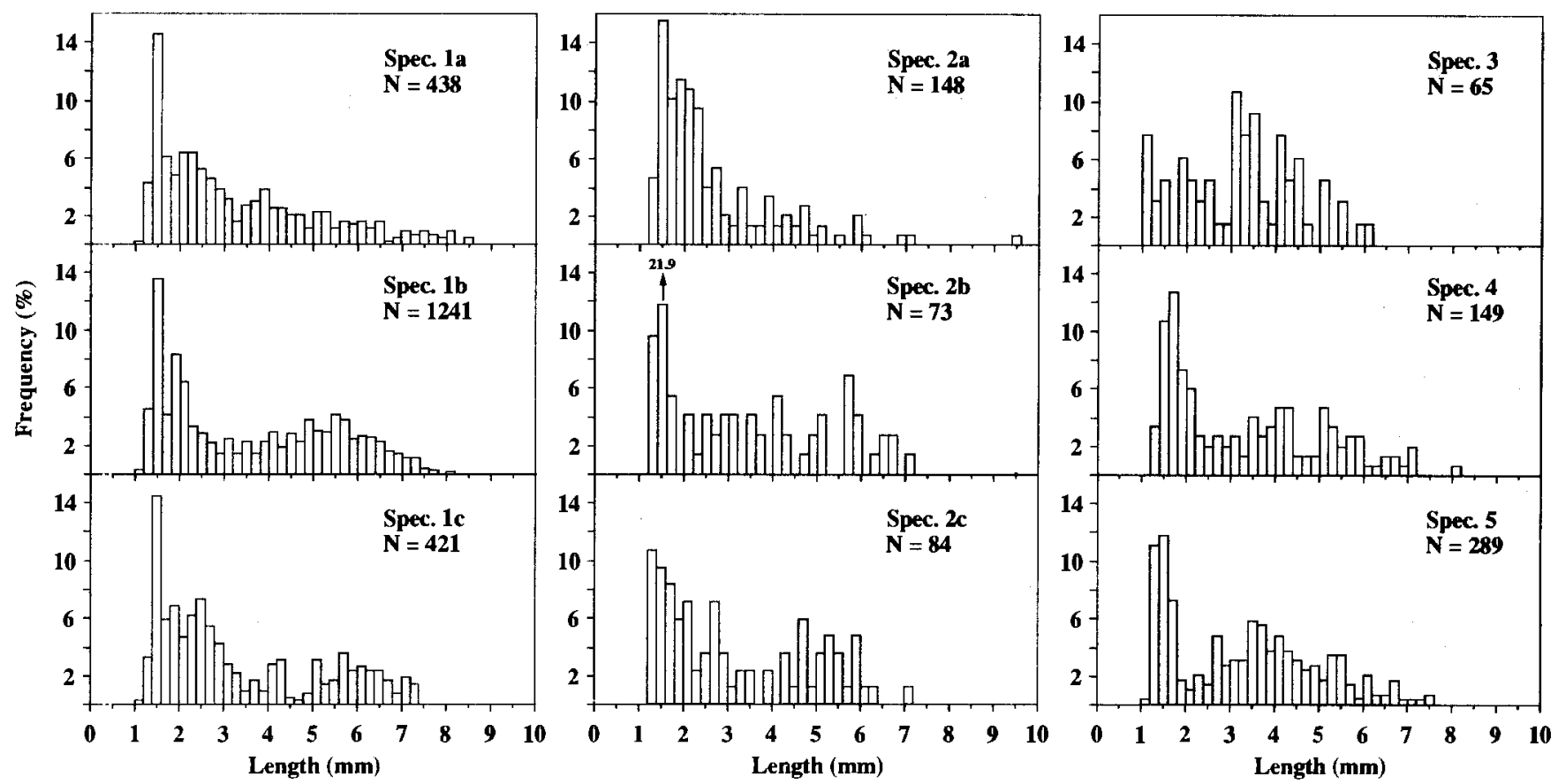

Fig. 3. Shell length-frequency distributions of L. notorcadensis inhabiting the nine sea urchins (spec. numbers refer to Table 1)

Table 2. Correlation among cidaroid diameter $(\mathrm{mm})$, position of spine on the aboralo al axis $\left(0^{\circ}-180^{\circ}\right)$, spine length $(\mathrm{mm})$, a ount of other epizoa per spine (mm spine length) and number of $L$ notorcacensis per spine (N). 342 Data sets, * indicates significant correlation at $x=0.05$

\begin{tabular}{llllc}
\hline & Cidaroid diameter $\begin{array}{l}\text { Aboral-oral axis } \\
\text { position }\end{array}$ & Spine length & Other epizoa \\
\hline Cidaroid diameter & 1 & & & \\
A-O axis position & 0.015 & 1 & & \\
Spine length & $0.168^{*}$ & $-0.288^{*}$ & 1 & \\
Other epizoa & 0.022 & $-0.188^{*}$ & $0.655^{*}$ & 1 \\
N/Spine & $0.146^{*}$ & $-0.326^{*}$ & $0.379^{*}$ & $-0.144^{*}$ \\
\hline
\end{tabular}

relation $(P=0.064)$ between recruitment success and the biomass already present (Fig. 4):

$$
\begin{aligned}
\log \left(\mathrm{N}_{\text {juv }} / \mathrm{N}_{\text {emb }}\right) & =-0.542-0.218 \cdot \log \left(B_{\text {adult }}\right) \\
\mathrm{N} & =9 ; \mathrm{r}=-0.640
\end{aligned}
$$

\section{Distrib.tion on spines}

342 spines of the six sea urchins were used for the analysis of the cistribution of $L$. notorcadensis. Spines partially lost were included to improve statistical power, assuming a randor 1 distribution of single bivalves and of bivalve patches along the spines. A preliminary analysis of correlation an ong the parameters in question showed the number of $l$. notorcadensis per spine to be correlated positively to sea urchin diameter and spine length, and negatively to spine position on the aboral-oral axis and the amount of other !.pizoa (Table 2, Fig. 5). Spine length is related significantly to diameter and position on the aboral-oral axis (see Fig. 2), whereas the amount of other epizoa is related to spine length and position on the aboral-oral axis (Table 2).

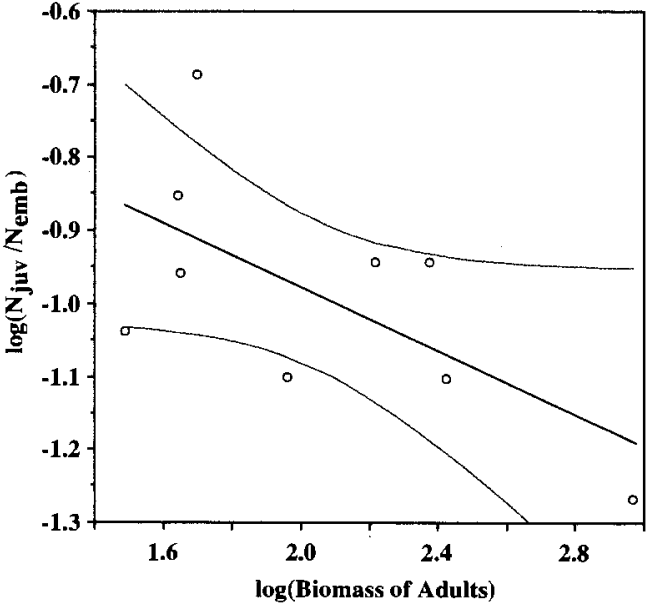

Fig. 4. Relation between the biomass of $L$. notorcadensis on a cidaroid (B, sum of all specimens $>1.7 \mathrm{~mm}$ length) and recruitment success (number of juveniles $\leqq 1.7 \mathrm{~mm}$ as fraction of total number of embryos brooded by the population). $\log \left(\mathrm{N}_{\text {juv }} / \mathrm{N}_{\text {emb }}\right)=-0.542$ $-0.218 \cdot \log \left(\mathrm{B}_{\text {adult }}\right) ; N=9 ; \mathrm{r}=-0.640 ; P=0.064 ;$ Curved lines represent the $95 \%$ confidence bands for the true mean of $\log \left(\mathrm{N}_{\mathrm{juv}} / \mathrm{N}_{\mathrm{emb}}\right)$ 

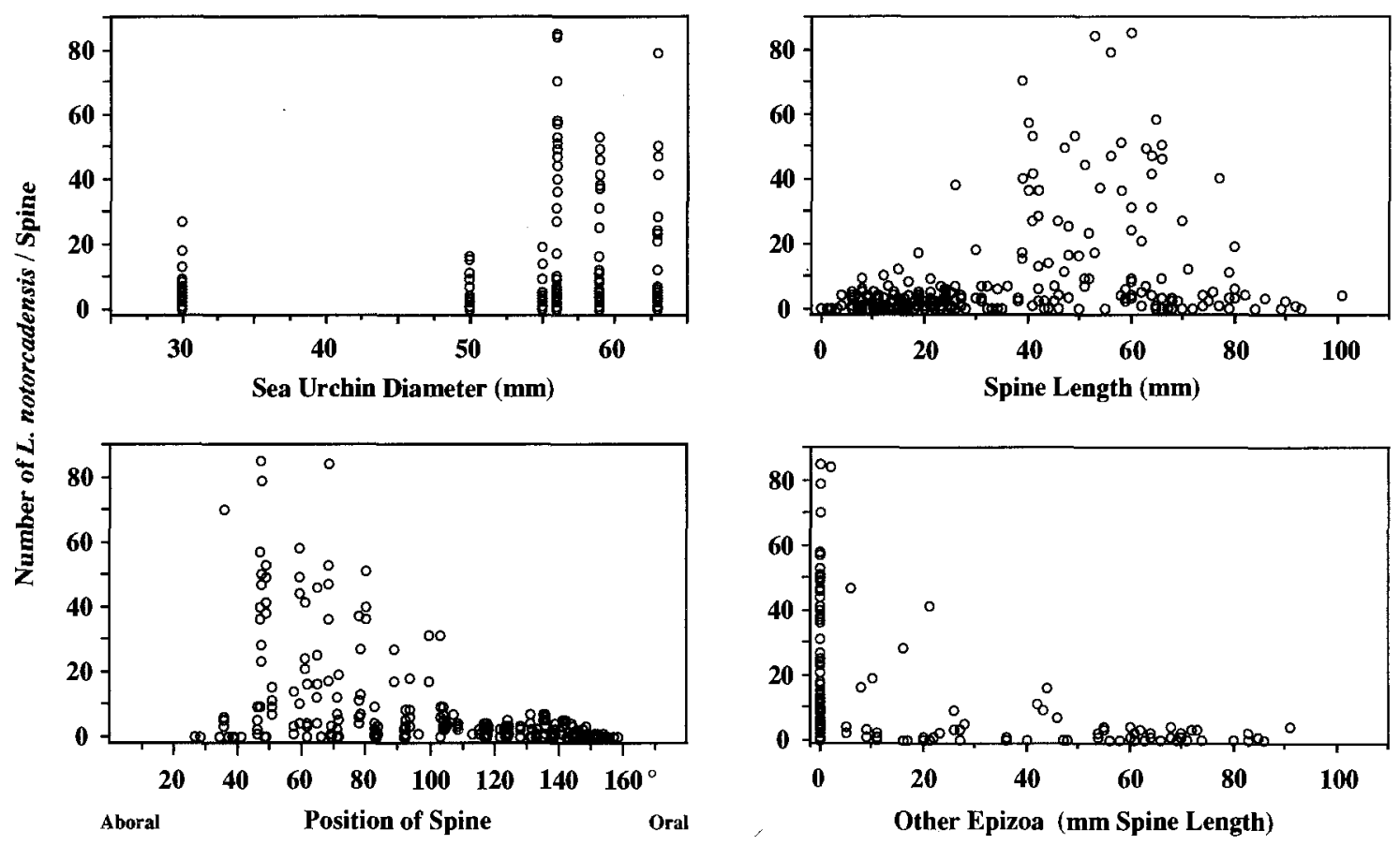

Fig. 5. The number of $L$. notorcadensis per sea urchin spine in relation to sea urchin diameter, spine length, position of spine on the aboral-oral axis, and amount of other epizoa ( $N=342$ spines from six sea urchins)

For the analysis of variance (ANOVA) the number of L. notorcadensis per spine was divided by spine length ( 24 spines of length $\leqslant 0.5 \mathrm{~mm}$ were excluded) to remove the effect of this parameter, and the variables "spine position on the aboral-oral axis" as well as "amount of other epizoa" were re-grouped into categories. The four-factor ANOVA found the number of bivalves per millimetre of spine to be significantly affected by the sea urchin specimen, by the position on the aboral-oral axis, and by the occupation of spines by other epizoa, whereas there is no effect of the interambulacral sector (Table 3A). Post-hoc tests showed the number of bivalves per millimetre of spine (N) to be significantly higher in the sea urchin specimens $1 \mathrm{~b}$ (mean $N=0.52$ ) and la (mean $N=0.21$ ), in the range $40^{\circ}-60^{\circ}$ on the aboral-oral axis (mean $N=0.50$ ), and on spines with no other epizoa (mean $N=0.21$, Tables 3B and $3 \mathrm{C}$ ).

\section{Discussion}

\section{Sampling effects}

Sampling by the Agassiz trawl caused damage to most of the sea urchins collected, spines were partially or completely lost (Table 1). This leads to an under-estimation of abundance, biomass and production estimates. Lengthfrequency distributions and parameters such as $\mathrm{P} / \mathrm{B}$ ratio and recruitment success seem to be unbiased, since there are no clear hints for size-selective loss of bivalves during sampling. An exception may be sea urchin no. 3, where small $(\leq 2 \mathrm{~mm})$ as well as large $(\geq 6.5 \mathrm{~mm})$ Lissarca specimens seem to be under-represented (Fig. 3). However, beside sampling, station-specific effects, different stages of colonization and interspecific competition for space on the spines may be responsible for the high variability of abundance and biomass of $L$. notorcadensis among the nine specimens of Notocidaris sp. (Table 1).

\section{Somatic and gonad production}

The three cidaroids sampled on the northern shelf carry sub-populations of $L$. notorcadensis with distinctly higher abundance, biomass and production than those collected on the southeastern shelf (Table 1). These differences should be interpreted cautiously, since sample size is quite small, but they may be related to the better food supply in the north. Sedimentation on the northern Weddell Sea shelf may reach values well above $15 \mathrm{~g} \mathrm{C}_{\text {org }} \mathrm{m}^{-2} \mathrm{y}^{-1}$ (estimated from Bodungen et al. 1986), whereas sedimentation on the southeastern Weddell sea shelf is in the range of $5 \mathrm{~g} \mathrm{C}_{\text {org }} \mathrm{m}^{-2} \mathrm{y}^{-1}$ (Bodungen et al. 1988, Bathmann et al. 1991). However, the $\mathrm{P} / \mathrm{B}$ ratios of the nine subpopulations do not differ very much (Table 1), indicating that the different food level mainly affects the carrying capacity but not productivity.

If growth efficiency (Production/Consumption) of $L$. notorcadensis is in the range of about $10 \%$ (see e.g. Hughes 1970, Hummel 1985, Rodhouse et al. 1981, Streit 1976), the nine sub-populations investigated require between $82 \mathrm{mg} \mathrm{C}_{\text {org }}$ (cidaroid no. 3) and $2437 \mathrm{mg} \mathrm{C}_{\text {org }}$ (cidaroid no. $1 \mathrm{~b})$ of food per year $\left(1 \mathrm{mg} A F D M=0.5 \mathrm{mg} \mathrm{C}_{\text {org }}\right.$, Table 4). The amount of sedimenting matter theoretically available for a Lissarca sub-population can be calculated from the bottom area covered by the sea urchin, i.e. [(test diam. $+2 \cdot \max$ spine length) $/ 2]^{2} \cdot \pi$. Only in the cidaroid specimens nos. $2 \mathrm{~b}, 2 \mathrm{c}$, and 3 do sedimentation rates meet 
Table 3. Analysis of Variance (ANOVA) of the distribution of $L$. notorcadensis on cidaroid spines
A ANOVA

\begin{tabular}{llllrl}
\hline Source & $\begin{array}{l}\text { Degrees of } \\
\text { Freedom }\end{array}$ & $\begin{array}{l}\text { Sum of } \\
\text { Squares }\end{array}$ & $\begin{array}{l}\text { Mean } \\
\text { Square }\end{array}$ & F & $P$ \\
\hline Cidaroid Specimen & 5 & 0.446 & 0.089 & 19.803 & 0.0001 \\
Interambulacral Sector & 4 & 0.013 & 0.003 & 0.707 & 0.5873 \\
Aboral-Oral Axis Position7 & 3 & 0.690 & 0.115 & 25.538 & 0.0001 \\
Other Epizoa & 300 & 0.104 & 0.052 & 11.539 & 0.0001 \\
Residual & 1.351 & 0.005 & & \\
\hline
\end{tabular}

B Mean; Table (mean number of L. notorcadensis per mm spine length and standard deviation)

\begin{tabular}{|c|c|c|c|c|c|c|c|c|c|c|c|}
\hline \multicolumn{4}{|c|}{ Cidaroic: Specimen } & \multicolumn{4}{|c|}{ Position of Spine (Deg) } & \multicolumn{4}{|c|}{ Other Epizoa } \\
\hline & Count & Mean & S.D. & & Count & Mean & $\mathrm{SD}$ & & Count & Mean & SD \\
\hline $1 \mathrm{a}$ & 51 & 0.213 & 0.339 & $20-40$ & 15 & 0.247 & 0.511 & $<1 / 3$ & 259 & 0.214 & 0.340 \\
\hline $1 b$ & 51 & 0.522 & 0.468 & $40-60$ & 41 & 0.495 & 0.502 & $<2 / 3$ & 12 & 0.124 & 0.177 \\
\hline $1 \mathrm{c}$ & 64 & 0.146 & 0.250 & $60-80$ & 43 & 0.293 & 0.368 & $>2 / 3$ & 47 & 0.033 & 0.063 \\
\hline $2 \mathrm{a}$ & 56 & 0.137 & 0.213 & $80-100$ & 37 & 0.205 & 0.252 & & & & \\
\hline $2 \mathrm{~b}$ & 42 & 0.041 & 0.079 & $100-120$ & 31 & 0.175 & 0.219 & & & & \\
\hline \multirow[t]{2}{*}{$2 c$} & 54 & 0.043 & 0.080 & $120-140$ & 50 & 0.114 & 0.143 & & & & \\
\hline & & & & $140-160$ & 101 & 0.032 & 0.067 & & & & \\
\hline
\end{tabular}

C Bonfer :oni/Dunn post-hoc test of differences between means (*: signif. difference at $\alpha=0.05)$

\begin{tabular}{|c|c|c|c|c|c|c|c|c|c|c|c|c|c|c|c|}
\hline \multicolumn{6}{|c|}{ Cidaroic Specimen } & \multicolumn{7}{|c|}{ Position of Spine (Deg) } & \multicolumn{3}{|c|}{ Other Epizoa } \\
\hline & $1 a$ & $1 b$ & $1 \mathrm{c}$ & $2 a$ & $2 b$ & & $20-40$ & $40-60$ & $6-80$ & -100 & -120 & -140 & & $<1 / 3$ & $<2 / 3$ \\
\hline 1a & 1 & & & & & $20-40$ & 1 & & & & & & $<1 / 3$ & 1 & \\
\hline $1 b$ & * & 1 & & & & $40-60$ & - & 1 & & & & & $<2 / 3$ & - & 1 \\
\hline $1 \mathrm{c}$ & - & * & 1 & & & $60-80$ & - & * & 1 & & & & $>2 / 3$ & $*$ & - \\
\hline $2 \mathrm{a}$ & - & $*$ & - & 1 & & -100 & - & * & - & 1 & & & & & \\
\hline $2 b$ & $*$ & $*$ & - & - & 1 & -120 & - & * & - & - & 1 & & & & \\
\hline $2 \mathrm{c}$ & $*$ & $*$ & - & - & - & -140 & - & $*$ & $*$ & - & - & 1 & & & \\
\hline & & & & & & -160 & * & * & * & $*$ & $*$ & - & & & \\
\hline
\end{tabular}

Dependent variable: $\log \left(1+\mathrm{N} \mathrm{mm}^{-1}\right), \mathrm{N} \mathrm{mm}^{-1}=$ Number per $\mathrm{mm}$ spine length. Independent variables: Sea urchin specimen; interamk slacral sector; position of spine on aboral-oral axis ( 7 segments of $20^{\circ}$ width); other epizoa (covering $<=1 / 3,<=2 / 3,>2 / 3$ of spine length)

Table 4. Production, food requirements and food availability

\begin{tabular}{lcclll}
\hline $\begin{array}{l}\text { Cidaroid } \\
\text { Specimen }\end{array}$ & $\begin{array}{l}\mathrm{P}_{\mathrm{t}} \\
\left(\mathrm{mgC}_{\text {org }} \mathrm{y}^{-1}\right)\end{array}$ & $\begin{array}{l}\mathrm{C} \\
\left(\mathrm{mgC}_{\text {org }} \mathrm{y}^{-1}\right)\end{array}$ & $\begin{array}{l}\text { Cidaroid } \\
\text { area }\left(\mathrm{cm}^{2}\right)\end{array}$ & $\begin{array}{l}\mathrm{S} \\
\left(\mathrm{mgC}_{\text {org }} \mathrm{y}^{-1}\right)\end{array}$ & $\mathrm{C} / \mathrm{S}$ \\
\hline la & 66.1 & 661.1 & 377 & 565.5 & 1.2 \\
$1 \mathrm{~b}$ & 243.7 & 2437.2 & 346 & 519.0 & 4.7 \\
$1 \mathrm{c}$ & 59.8 & 597.6 & 317 & 475.5 & 1.3 \\
$2 \mathrm{a}$ & 14.4 & 143.5 & 133 & 66.5 & 2.2 \\
$2 \mathrm{~b}$ & 9.7 & 96.9 & 519 & 259.5 & 0.4 \\
$2 \mathrm{c}$ & 10.9 & 109.2 & 394 & 197.0 & 0.6 \\
3 & 8.3 & 82.6 & 360 & 180.0 & 0.5 \\
4 & 20.8 & 207.7 & 104 & 52.0 & 4.0 \\
5 & 39.5 & 395.0 & 216 & 108.0 & 3.7 \\
\hline
\end{tabular}

$\mathrm{P}_{\mathrm{t}}$ : total production of $L$. notorcadensis per sea urchin, C: Consumption of $L$. notorcadensis per sea urchin if $\mathrm{P}_{t} / \mathrm{C}=10 \%, \mathrm{~S}$ : Sedimentation per sea urchin calculated from a rate of $15 \mathrm{~g} \mathrm{C}_{\mathrm{org}} \mathrm{m}^{-2} \mathrm{y}^{-1}$ on the northern shelf and $5 \mathrm{~g} \mathrm{C}_{\mathrm{org}} \mathrm{m}^{-2} \mathrm{y}^{-1}$ on the southeastern shelf

consumption of the Lissarca sub-populations, in the other six specimens, sedimentation is below consumption by a factor c. 1.2 to 4.7 (Table 4). It is unlikely that underestimation of sedimentation and/or growth efficiency of $L$. notoriadensis can account completely for this discre- pancy, so there must be additional food sources for the bivalve beside the direct input of organic matter from the pelagic system. These additional sources could be dissolved organic matter (DOM) and/or resuspended particulate organic matter (POM). Many marine invertebrates 
are able to aquisite DOM from seawater (Manahan et al. 1983; Manahan 1990), however, nothing is known about DOM uptake in L. notorcadensis. Sediment trap data from the southeastern Weddell Sea shelf indicate that resuspension of POM could provide additional food for suspension feeding species. At one station off Kapp Norvegia, a near-bottom sediment trap deployed at $600 \mathrm{~m}$ depth collected about 6 times more material $(47 \mathrm{~g} \mathrm{DM}$ $\left.\mathrm{y}^{-1}\right)$ than a trap at $270 \mathrm{~m}$ depth $\left(8 \mathrm{~g} \mathrm{DM} \mathrm{y}^{-1}\right.$, Arntz et al. 1992). The motility of the cidaroids could play a significant role too. The deposit feeding sea urchins may search actively for sediment patches rich in organic matter, which would in turn increase the amount of food provided for the epizoic bivalves by resuspension.

Reproductive effort, i.e. $100 \cdot$ gonad production/total production, is $27 \%$ on the average, which is in the upper range of iteroparous (i.e. multiple breeding) mollusc species (see Browne and Russell-Hunter 1978). This may indicate that $L$. notorcadensis is forced by the harsh environmental conditions - scarce and oscillating food supply and low temperature (see Clarke 1988) - to invest comparatively more energy in reproduction to increase the probability of individual survival of the offspring (see e.g. Christiansen and Fenchel 1979).

\section{Colonization and dispersal}

Adult $L$. notorcadensis are hemisessile, therefore sea urchins usually will be colonized by freshly released juveniles, which may be able to drift with water currents using mucus threads, as described by Martel and Chia (1991) for several boreal molluse species lacking planktonic larval stages. Occasional findings of juveniles distant from the adults in laboratory aquaria strengthen this assumption. Most of the larger (test diameter $\geqq 20 \mathrm{~mm}$ ) cidaroids found in trawl samples are colonized by at least some L. notorcadensis. Smaller specimens are either avoided

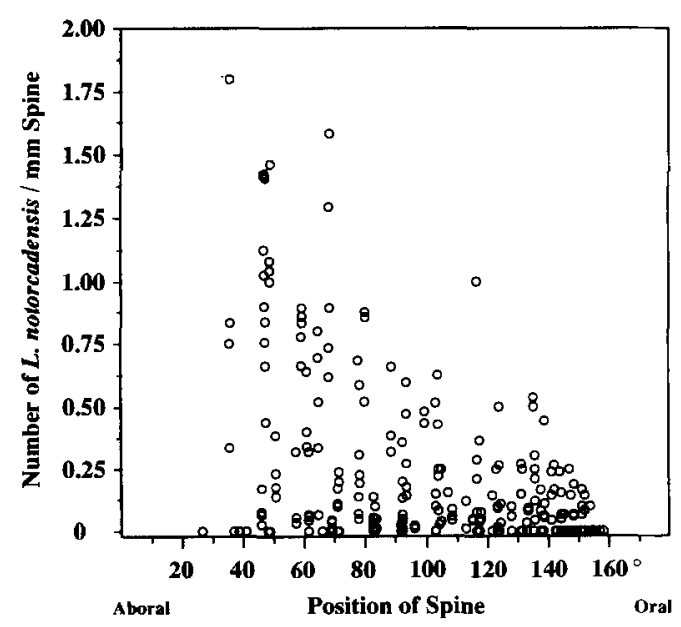

Fig. 6. The number of L. notorcadensis per millimeter of sea urchin spine in relation to the position of the spine on the aboral-oral axis $(N=318$ spines from six sea urchins, the spines $<0.5 \mathrm{~mm}$ length present on most of the interambulacral plates No. 1 are excluded) actively, or they just did not live long enough to encounter a drifting Lissarca juvenile. However, taking into account that the average distance between adjacent specimens of cidaroids is about $6 \mathrm{~m}$ in the Weddell Sea area (mean abundance $=0.04$ ind. $\mathrm{m}^{-2}$, range: $0-0.36$ ind. $\mathrm{m}^{-2}$; unpubl. data of foto counts by J. Gutt, AWI), the nearbottom water currents on the Weddell Sea shelf (see above) seem to be strong enough for an effective dispersal of drifting juveniles. Exchange of juveniles among different specimens could be further enhanced by periodic feeding or breeding aggregations of the sea urchins, as observed in a bathyal cidaroid species (Young et al. in press fide Tyler et al. 1992).

\section{Distribution on spines}

The inclusion of broken spines in the analysis may have affected the relation between $L$. notorcadensis number per spine and other parameters to a certain extend (Table 2, Fig 5), but the transformation to number per millimetre spine length should have eliminated this effect from the further analysis.

$L$. notorcadensis prefers to settle on those spines between $30^{\circ}-60^{\circ}$ on the aboral hemisphere of a cidaroid (Fig 6, Table 3), although the adjacent spines are not morphologically different. This particular distribution indicates that $L$. notorcadensis tries to settle at a position as high as possible above the sediment surface, most likely to improve its feeding conditions. In large cidaroids, the upper spines may reach well above the laminar boundary layer, which would provide a substantial advantage for $L$. notorcadensis with respect to the access to sedimenting matter (Jumars and Gallagher 1982).

In this context it is worth to note that $L$. notorcadensis is found very rarely on stones and boulders which may reach even higher into the water column, but almost exclusively on spines of cidaroids and occasionally on branches of hydrozoan and bryozoan colonies. These particular sites may either protect $L$. notorcadensis from crawling predators, e.g. amphipods, polychaetes or sea urchins, which may be not able to climb on thin branches or spines, or the hydrodynamic conditions around thin branches or spines are preferable to those along the surface of large objects.

The concentration of L. notorcadensis on the upper spines rises the question of intraspecific competition for space, because space is obviously limited. The negative relation between biomass already present and recruitment success (Fig. 4) gives evidence that there is competition for space. The higher the bivalve biomass already present on a particular cidaroid, the lower is the number of juvenile Lissarca settling on this sea urchin as fraction of the number of embryos produced. The importance of the proper position of the spines for L. notorcadensis is strengthened by the fact that the juveniles seem to drift away preferably than settle on the lower spines of their parent's sea urchin. However, the overall low recruitment success (mean $=0.11$ ) indicates that a great part of the juveniles drifts away even if there is sufficient space 
availatle. This high dispersion rate $(0.89$, i.e. 1 - recruitment success) may counteract the problem of genetical isolation otherwise faced by spatially isolated sub-populations without pelagic larval stages.

The correlation matrix (Table 2) and the results of the ANOVA (Table 3) indicate strong negative interactions between $L$. notorcadensis and other epizoic taxa (mainly colonial anthozoans and bryozoans). L. notorcadensis as well as the colonial species prefer the same spines for settlement, but they do not co-exist in the same area of a cidaroid spine. L. notorcadensis juveniles seem to be unable to attach themselves on the surface of the colonial epizoa, whereas dense aggregations of $L$. notorcadensis seem to prevent the initial settlement of the colonial species (Fig. 5).

To sum up, food availability, intraspecific competition and in erspecific competition are likely to be the main factors determining the distribution of $L$. notorcadensis among and along the sea urchin spines, whereas the significance of predation (Prezant 1989) remains uncertain.

\section{Referelıces}

Arntz WE, Brey T, Gerdes D, Gorny M, Gutt J, Hain S, Klages M (in press) Patterns of life history and population dynamics of bent ic invertebrates under high Antarctic conditions of the Wed lell Sea. Proceedings of the 25th European Marine Biology Symosium (E.M.B.S.) held at Ferrara, Italy, September 10-15, 1990

Bathmån U, Fischer G, Müller PJ, Gerdes D (1991) Short-term varia ions in particulate matter sedimentation off Kapp Norvegic, Weddell Sea, Antarctica: Relation to water mass advection, ice cover, plankton biomass and feeding activity. Polar Biol $11: 185-195$

Bodung:n Bv, Smetacek V, Tilzer MM, Zeitschel B (1986) Primary production and sedimentation during spring in the Antarctic penimsula region. Deep-Sea Res 33:177-194

Bodung $\cong \mathrm{n} \mathrm{Bv}$, Nöthig E-M, Sui Q (1988) New production of phytoplankton and sedimentation during summer 1985 in the soutl;-eastern Weddell Sea. Comp Biochem Physiol 90B:475-487

Brey T, Hain S (1992) Growth, reproduction and production of Lissarca notorcadensis (Bivalvia: Philobryidae) on the Weddell Sea shelf, Antarctica, Mar Ecol Prog Ser 82:219-226

Browne RA, Russell-Hunter WD (1978) Reproductive effort in mollusse. Oecologia 37:23-27

Christiansen FB, Fenchel TM (1979) Evolution of marine invertebrate reproductive patterns. Theor Pop Biol 16:267-282
Clarke A (1988) Seasonality in the Antarctic marine environment. Comp Biochem Physiol 90B:461-473

Crisp DJ (1984) Energy flow measurements. In: Holme, N.A. McIntyre, AD (eds.) Methods for the study of marine benthos. Blackwell, London 284-372

Dell, RK (1990) Antarctic Mollusca. With special reference to the fauna of the Ross Sea. Royal Society of New Zealand Bulletin $27: 1-311$

Hughes RN (1970) An energy budget for a tidal-flat population of the bivalve Scrobicularia plana (Da Costa). J Anim Ecol 39:357-381

Hummel H (1985) An energy budget for a Macoma balthica (Mollusca) population living on a tidal flat in the Dutch Wadden Sea. Neth J Sea Res 19:84-92

Janssen HJ (1990) Öko-histologische Untersuchungen an Lissarca notorcadensis (Philobryidae: Bivalvia). Verh Dtsch Zool Ges 83:602

Jumars PA, Gallagher ED (1982) Deep-Sea community structure: three plays on the benthic proscenium. In: Ernst WG, Morin JG (eds) The environment of the Deep Sea. Prentice Hall, Englewood Cliffs, USA

Manahan DT (1990) Adaptations by invertebrate larvae for nutrient aquisition from seawater. Am Zool 30:147-160

Manahan DT, Wright SH, Stephens GC (1983) Simultaneous determination of net uptake of 16 amino acids by a marine bivalve. Am J Physiol 244:R832-R838

Martel A, Chia F-S (1991) Drifting and dispersal of small bivalves and gastropods with direct development. J Exp Mar Biol Ecol 150:131-147

Mortensen T (1909) Die Echinoiden der deutschen Südpolar-Expedition 1901-1903. In: Drygalki Ev (ed) Deutsche SüdpolarExpedition 1901-1903. Bd XI, Zool III, Heft1. Reimer, Berlin

Mortensen T (1920) The Echinoidea of the Swedish South Polar Expedition. In: Nordensköld O (ed) Wiss Ergebnisse der Schwedischen Südpolar-Expedition 1901-1903. Bd VI, Zool II, Lief 4. Asher \& Co, Berlin; Haar \& Steiner, Eichler, Paris; Dulau \& Co, London

Mortensen T (1943) A monograph of the Echinoidea, vol III. Reitzel, Copenhagen

Prezant RS (1989) Distribution of the bivalve Lissarca notorcadensis on echinoid spines (Abstract). Am Zool 29:9A

Rodhouse PG, Ottway B, Burnell GM (1981) Bivalve production and food chain efficiency in an experimental nursery system. J Mar Biol. Ass UK 61:243-256

Streit B (1976) Energy flow in four different populations of Ancylus fluviatilis (Gastropoda-Basommatophora). Oecologia 22:261-273

Tyler PA, Young CM, Billett DSM, Giles LA (1992) Pairing behaviour, reproduction and diet in the deep sea holothurian genus Paroriza (Holothuroidea: Synallactidae. J Mar Biol Ass UK 72:447-462

Young CM, Tyler PA, Cameron JL, Rumrill SS (1992) Seasonal breeding aggregations in low-density populations of the bathyal (cidaroid) echinoid Stylocidaris lineata. Mar Biol 113:603-612 